\title{
Seasonal Dynamics of Phytoplankton and Some Hydrochemical Indicators of the Peipsi-Pskov Lake
}

\author{
Tatiana Drozdenko \\ Pskov State University \\ Pskov, Russia \\ email: tboichuk@mail.ru
}

\author{
Sergei Fedorov \\ Pskov Center for Hydrometeorology \\ and Environmental Monitoring \\ Pskov, Russia \\ email: nexx.89@mail.ru
}

\author{
Irina Kek \\ Pskov State University \\ Pskov, Russia \\ email: fedorovairina1996@yandex.ru
}

\begin{abstract}
The Peipsi-Pskov Lake is the largest freshwater body in Europe, ranking fourth in area and fifth in volume. It is characterized by shallow water and a high level of trophy. The water in the lake is poorly mineralized and has little transparency due to suspended sediments and the development of plankton. Phytoplankton acts as a primary link in trophic chains, quickly reacts to changes in the aquatic environment and serves as a convenient object in monitoring studies.

The average concentrations of total nitrogen in the lake during the observation period were in the range of 525 $818 \mu \mathrm{g} / \mathrm{dm}^{3}$. The content of ammonium, nitrate, and nitrite nitrogen in the samples was mostly below the detection limits. The values of total phosphorus varied from $20 \mu \mathrm{g} / \mathrm{dm}^{3}$ to 54 $\mu \mathrm{g} / \mathrm{dm}^{3}$, and its concentrations were lower than the sensitivity of the method during the flood recession.

The maximum values of total nitrogen and phosphorus were recorded in August: in Lake Peipsi - $1.12 \mathrm{mg} / \mathrm{dm}^{3}$ and $0.09 \mathrm{mg} / \mathrm{dm}^{3}$, in Lake Pskov - $1.59 \mathrm{mg} / \mathrm{dm}^{3}$ and $0.14 \mathrm{mg} / \mathrm{dm}^{3}$, respectively. BOD values ranged from $1.96 \mathrm{mg} / \mathrm{dm}^{3}$ in autumn to $4.26 \mathrm{mg} / \mathrm{dm}^{3}$ in summer.

During the growing season of 2020, 244 species taxa of phytoplankton from 8 phylums were identified in the PeipsiPskov Lake: Chlorophyta, Bacillariophyta, Cyanobacteria, Chrysophyta, Euglenophyta, Cryptophyta, Dinophyta and Xanthophyta. Floristic complex was characterized as chlorophyta-diatom-cyanobacterial.

The number of phytoplankton varied between 2.1 and 16.2 million cells/l depending on the season. The average number was 7.6 million cells/l. The biomass values ranged from $0.9 \mathrm{~g} / \mathrm{m}^{3}$ to $3.6 \mathrm{~g} / \mathrm{m}^{3}$. The average biomass was $2.3 \mathrm{~g} / \mathrm{m}^{3}$.

According to the ecological and geographical characteristics of the lake, widespread freshwater forms of microalgae predominated, preferring stagnant-flowing, slightly alkaline waters.
\end{abstract}

Saprobiological analysis showed that the waters of the Peipsi-Pskov Lake were classified as moderately polluted, class III of water purity quality.

Keywords - environmental monitoring, hydrochemical indicators, Peipsi-Pskov Lake, phytoplankton.

\section{INTRODUCTION}

Peipsi-Pskov Lake is located on the border between Estonia and the Pskov and Leningrad regions of Russia, and is the fourth largest lake in Europe. The area of the water mirror of the lake at an average water level is 3555 $\mathrm{km}^{2}$, the volume is $25 \mathrm{~km}^{3}$, the average depth is $7.1 \mathrm{~m}$, the largest is $15.3 \mathrm{~m}$. The height above sea level is $30 \mathrm{~m}$. Lake Peipsi is an unstratified eutrophic lake. The water, especially in the southern part of the lake, is rich in nutrients. The lake is characterized by high productivity. Macrophytes occupy 5-8 \% of the entire water area. The lake is home to more than 30 species of fish [1].

Currently, Peipsi-Pskov Lake is experiencing a significant anthropogenic load associated with the discharge of wastewater in the catchment area, as well as at the expense of agricultural facilities [2]. Along with biogenic pollution, the lake experiences significant pollution with heavy metals and detergents associated with the development of industry in the catchment area [3].

Phytoplankton is the most important component of aquatic ecosystems, actively participating in the formation of water quality. Planktonic algae are the primary link in the trophic chains and react quickly to any changes in the aquatic environment, changing their structural parameters. The indicator properties of phytoplankton are determined not only by the fact of the presence or absence of certain 
species, but also by the degree of their quantitative development. Therefore, the study of such structural indicators as the species composition, abundance and biomass of algae in the reservoir is of great practical importance [4], [5], [6], [7].

Seasonal dynamics of phytoplankton is associated with changes in abiotic conditions in the annual cycle, as well as fluctuations in hydrochemical parameters [8]. By studying the qualitative and quantitative composition of the phytoplankton of the reservoir, it is possible to determine the main changes that occur in it during the biological seasons of the year.

In this regard, the purpose of this work was to study the seasonal dynamics of phytoplankton and some hydrochemical parameters of the Peipsi-Pskov Lake.

\section{MATHERIALS AND METHODS}

Studies in the Peipsi-Pskov Lake were conducted in 2020 in spring (May), summer (August) and autumn (October).

Hydrobiological and hydrochemical samples were taken in parallel at permanent monitoring stations (Fig. 1) by conventional methods [9], [10].

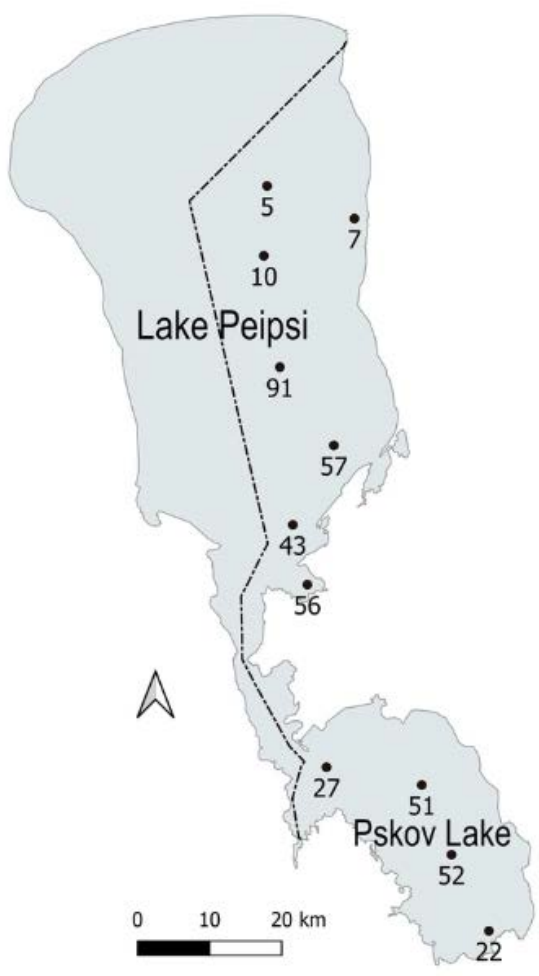

Fig. 1. Permanent sampling stations in the Peipsi-Pskov Lake

In the spring-summer period of observations, the water temperature, depending on the horizon, was $0.5-0.7{ }^{\circ} \mathrm{C}$ higher in Lake Pskov than in Lake Peipsi (Table 1). In October, the water of Lake Peipsi was slightly warmer. The acidity of the medium in all seasons was slightly alkaline, with the highest values in the summer. The oxygen content in the Pskov and Peipsi lakes did not differ much, except for the spring period, where the oxygen content was higher in Lake Peipsi. This is probably due to the fact that the processes of destruction were more active in Lake Pskov, so the oxygen consumption was higher.

TABLE 1 MAIN ABIOTIC FACTORS OF THE PEIPSI-PSKOV LAKE, 2020

\begin{tabular}{|c|c|c|c|c|}
\hline \multirow{2}{*}{ Indicator } & \multicolumn{2}{|c|}{ Lake Pskov } & \multicolumn{2}{|c|}{ Lake Peipsi } \\
\hline & $0.5 \mathrm{~m}$ & bottom & $0.5 \mathrm{~m}$ & bottom \\
\hline \multicolumn{5}{|c|}{ May } \\
\hline t. $\mathrm{C}^{\mathrm{O}}$ & $10.4 \pm 0.3$ & $10.1 \pm 0.2$ & $9.9 \pm 0.5$ & $9.5 \pm 0.3$ \\
\hline $\mathrm{pH}$ & $8.2 \pm 0.1$ & $8.2 \pm 0.1$ & $8.3 \pm 0.1$ & $8.3 \pm 0.0$ \\
\hline $\mathrm{O}_{2}, \mathrm{mg} / \mathrm{l}$ & $10.8 \pm 0.6$ & $10.4 \pm 0.5$ & $12.9 \pm 0.7$ & $12.5 \pm 0.6$ \\
\hline \multicolumn{5}{|c|}{ August } \\
\hline t. $\mathrm{C}^{\mathrm{O}}$ & $20.0 \pm 0.3$ & $19.8 \pm 0.4$ & $19.4 \pm 0.5$ & $19.1 \pm 0.2$ \\
\hline $\mathrm{pH}$ & $8.8 \pm 0.0$ & $8.8 \pm 0.0$ & $8.6 \pm 0.2$ & $8.6 \pm 0.1$ \\
\hline $\mathrm{O}_{2}, \mathrm{mg} / \mathrm{l}$ & $9.2 \pm 0.4$ & $9.3 \pm 0.2$ & $9.0 \pm 0.5$ & $8.8 \pm 0.1$ \\
\hline \multicolumn{5}{|c|}{ October } \\
\hline t. $\mathrm{C}^{\mathrm{o}}$ & $12.5 \pm 0.1$ & $12.3 \pm 0.2$ & $13.0 \pm 0.1$ & $12.7 \pm 0.0$ \\
\hline $\mathrm{pH}$ & $8.1 \pm 0.1$ & $8.0 \pm 0.0$ & $8.2 \pm 0.1$ & $8.1 \pm 0.0$ \\
\hline $\mathrm{O}_{2}, \mathrm{mg} / \mathrm{l}$ & $9.5 \pm 0.4$ & $9.5 \pm 0.4$ & $9.7 \pm 0.7$ & $9,8 \pm 0.0$ \\
\hline
\end{tabular}

Hydrochemical studies included quantitative determination of the content of nitrite, nitrate and ammonium ions, biochemical oxygen consumption for 5 days $\left(\mathrm{BOD}_{5}\right)$, total and gross phosphorus concentrations, total and gross nitrogen, and total iron. The samples were analyzed using titrimetric and spectrophotometric methods in accordance with the methods of the HDPE F series [11], [12], [13], [14], [15], [16].

Phytoplankton samples were processed according to standard methods [17]. The similarity of the taxonomic composition of phytoplankton communities was analyzed using the Sierensen-Chekanovsky index [18]. The dominant species were those with a population of $10 \%$ or more of the total. For saprobiological analysis, the method of Pantle and Buck was used in the modification of Sladechek [19].

Statistical data processing and the construction of graphical images were carried out using the program "MO Excel".

\section{RESULTS AND DISCUSSION}

Hydrochemistry. Hydrochemical analysis has shown that the content of biogenic elements of the nitrogen and phosphorus groups is largely subject to seasonal fluctuations, which is a consequence of autochthonous biotic processes.

The average seasonal total nitrogen content was 525$818 \mu \mathrm{g} / \mathrm{dm}^{3}$ in Lake Peipsi and 604-839 $\mu \mathrm{g} / \mathrm{dm}^{3}$ in Lake Pskov. In the summer-autumn period, the concentration of total nitrogen was higher in Lake Pskov (Table 2).

The maximum content of total phosphorus in August was observed in Lake Pskov at station $27-20 \mu \mathrm{g} / \mathrm{dm}^{3}$, in Lake Peipsi - at station 7 - $38 \mu \mathrm{g} / \mathrm{dm}^{3}$. In October, the waters of Lake Pskov were characterized by a higher content of total phosphorus compared to Lake Peipsi. In the central part of the water area, its content reached $54 \mu \mathrm{g} / \mathrm{dm}^{3}$ (station 52), in the north-western part - $50 \mu \mathrm{g} / \mathrm{dm}^{3}$ (st. 27). The average amount of total phosphorus in the water area of Lake Pskov was $39 \mu \mathrm{g} / \mathrm{dm}^{3}$ (Table 2). 
Environment. Technology. Resources. Rezekne, Latvia Proceedings of the $13^{\text {th }}$ International Scientific and Practical Conference. Volume 1, 50-54

TABLE 2 HYDROCHEMICAL PARAMETERS OF LAKE PEIPSI-PSKOV

\begin{tabular}{|c|c|c|c|c|c|c|}
\hline & \multicolumn{3}{|c|}{ Lake Peipsi } & \multicolumn{3}{|c|}{ Lake Pskov } \\
\hline & May & August & October & May & August & October \\
\hline \multicolumn{7}{|c|}{$\mathrm{NH}_{4}^{+}, \mu \mathrm{g} / \mathbf{1}$} \\
\hline $\min$ & $<20$ & 20 & $<20$ & 20 & 20 & 20 \\
\hline mid & 20 & 20 & $<20$ & 43 & 24 & 28 \\
\hline $\max$ & 20 & 20 & $<20$ & 70 & 30 & 30 \\
\hline \multicolumn{7}{|c|}{$\mathrm{NO}_{3}{ }^{-}, \mu \mathrm{g} / 1$} \\
\hline $\min$ & 92 & $<50$ & $<50$ & 37 & $<50$ & $<50$ \\
\hline mid & 172 & $<50$ & $<50$ & 54 & $<50$ & $<50$ \\
\hline $\max$ & 314 & $<50$ & $<50$ & 61 & $<50$ & $<50$ \\
\hline \multicolumn{7}{|c|}{$\mathrm{N}$ total, $\boldsymbol{\mu g} / \mathbf{1}$} \\
\hline $\min$ & 525 & 548 & 570 & 604 & 758 & 629 \\
\hline mid & 652 & 639 & 583 & 652 & 798 & 680 \\
\hline $\max$ & 818 & 748 & 595 & 740 & 839 & 738 \\
\hline \multicolumn{7}{|c|}{ N gross, $\mu g / 1$} \\
\hline $\min$ & 667 & 658 & 646 & 783 & 1162 & 789 \\
\hline mid & 796 & 860 & 670 & 848 & 1378 & 925 \\
\hline $\max$ & 957 & 1137 & 702 & 895 & 1589 & 1000 \\
\hline \multicolumn{7}{|c|}{ P total, $\mu \mathrm{g} / \mathbf{1}$} \\
\hline $\min$ & $<20$ & 20 & $<20$ & $<20$ & $<20$ & 22 \\
\hline mid & $<20$ & 30 & $<20$ & $<20$ & $<20$ & 39 \\
\hline $\max$ & $<20$ & 38 & $<20$ & $<20$ & $<20$ & 54 \\
\hline \multicolumn{7}{|c|}{ P gross, $\mu \mathrm{g} / \mathbf{1}$} \\
\hline $\min$ & 20 & 24 & 26 & 32 & 1162 & 54 \\
\hline mid & 37 & 60 & 37 & 39 & 93 & 60 \\
\hline $\max$ & 68 & 92 & 56 & 47 & 1589 & 70 \\
\hline \multicolumn{7}{|c|}{ BOD $_{5}, \mathbf{m g} / \mathbf{1}$} \\
\hline $\min$ & 2.10 & 2.07 & 1.45 & 2.27 & 2.57 & 1.96 \\
\hline mid & 2.47 & 2.65 & 1.66 & 2.49 & 3.27 & 2.72 \\
\hline $\max$ & 2.91 & 3.84 & 1.79 & 2.75 & 4.26 & 3.36 \\
\hline \multicolumn{7}{|c|}{ Fe total, $\mu \mathrm{g} / 1$} \\
\hline $\min$ & $<20$ & 20 & 21 & 31 & 31 & 41 \\
\hline mid & 20 & 24 & 24 & 88 & 38 & 47 \\
\hline $\max$ & 184 & 31 & 25 & 214 & 51 & 53 \\
\hline
\end{tabular}

The average concentrations of gross forms of nitrogen and phosphorus in the spring period in Lake Peipsi were $796 \mu \mathrm{g} / \mathrm{dm}^{3}$ and $37 \mu \mathrm{g} / \mathrm{dm}^{3}$, respectively, in Lake Pskov $848 \mu \mathrm{g} / \mathrm{dm}^{3}$ and $39 \mu \mathrm{g} / \mathrm{dm}^{3}$, respectively. During the period of maximum water warming (August), the concentrations of total nitrogen and phosphorus were in Lake Peipsi - 860 $\mu \mathrm{g} / \mathrm{dm}^{3}$ and $60 \mu \mathrm{g} / \mathrm{dm}^{3}$, respectively, in Pskov - 1,4 $\mathrm{mg} / \mathrm{dm}^{3}$ and $93 \mu \mathrm{g} / \mathrm{dm}^{3}$, respectively (Table 2). By October, as the waters cooled and biological activity faded, the content of these biogens decreased and was comparable to the values of those at the beginning of the growing season.

Throughout the entire study period, no analytically significant amounts of nitrite nitrogen were detected in any of the selected samples.

In May, in the water area of Lake Peipsi, the average content of nitrate nitrogen was 3 times higher than in Pskov (Table 2).

The results of the studies showed a low level of ammonium nitrogen in Lake Peipsi (on average, $20 \mu \mathrm{g} / \mathrm{dm}^{3}$ ). In the Pskov lake, concentrations were significantly higher, but nevertheless the norms of maximum permissible concentrations for fishery water bodies. The content of mineral forms of phosphorus in all samples was below the sensitivity threshold of the method (Table 2).

The average content of easily oxidized organic matter (according to $\mathrm{BOD}_{5}$ ) in Lake Pskov in the spring-summer period varied from $2.07 \mathrm{mg} / \mathrm{dm}^{3}$ to $3.84 \mathrm{mg} / \mathrm{dm}^{3}$ (at $\mathrm{MAC}=2 \mathrm{mg} / \mathrm{dm}^{3}$ ). In autumn, the average BOD 5 was 1.66 $\mathrm{mg} / \mathrm{dm}^{3}$. In Lake Peipsi, the concentrations of easily oxidized organic matter, depending on the season of the year, were in the range of $1.96-4.26 \mathrm{mg} / \mathrm{dm}^{3}$ with the maximum values at stations located in the estuaries of large rivers (the Velikaya River and the Zhelcha River).

The total iron content in Lake Peipsi varied in the range of $24-46 \mathrm{mg} / \mathrm{dm}^{3}$, in Pskov - 38-88 mg/dm ${ }^{3}$, which corresponds to the long-term average values.

According to the conducted studies, the water quality of the Peipsi-Pskov Lake can be described as satisfactory in most hydrochemical indicators. The content of nutrients is comparable to the results of many years of research. The resulting excess of organic matter standards is caused by climatic and hydrometeorological features of the seasons.

Phytoplankton. In the water area of Lake Peipsi-Pskov in 2020, 244 species and intraspecific phytoplankton taxa were identified from 8 phylums: Chlorophyta, Bacillariophyta, Cyanobacteria, Chrysophyta, Euglenophyta, Cryptophyta, Dinophyta and Xanthophyta (Table 3). 201 species of phytoplankton taxa were identified in Lake Pskov, and 205 in Lake Peipsi. According to the Sorensen-Chekanovsky index, the degree of commonality of the species composition of the planktonic algoflora of both lakes was high and amounted to $79.8 \%$ (162 common species).

TABLE 3 TAXONOMIC COMPOSITION OF PHYTOPLANKTON OF LAKE PEIPSI-PSKOV IN 2020

\begin{tabular}{|l|c|c|c|c|c|}
\hline \multirow{2}{*}{ Phylums } & \multicolumn{3}{|c|}{$\begin{array}{c}\text { Number of phytoplankton } \\
\text { species, abs. }\end{array}$} & \multicolumn{2}{c|}{$\begin{array}{c}\text { For all the } \\
\text { time }\end{array}$} \\
\cline { 2 - 6 } & May & August & October & abs. & \% \\
\hline Chlorophyta & 62 & 68 & 53 & 89 & 36.5 \\
\hline Bacillariophyta & 65 & 59 & 43 & 83 & 34.0 \\
\hline Cyanobacteria & 25 & 31 & 23 & 36 & 14.8 \\
\hline Chrysophyta & 13 & 9 & 6 & 14 & 5.7 \\
\hline Euglenophyta & 8 & 3 & 1 & 9 & 3.7 \\
\hline Cryptophyta & 6 & 5 & 5 & 6 & 2.5 \\
\hline Dinophyta & 3 & 5 & 2 & 5 & 2.0 \\
\hline Xanthophyta & 2 & 2 & 1 & 2 & 0.8 \\
\hline Total: & 184 & 177 & 134 & \multicolumn{2}{c|}{244} \\
\hline
\end{tabular}

The genera Scenedesmus (8 species), Closterium (8) and Monoraphidium (7) from green algae; Surirella (11), Aulacoseira (8), Navicula (7) from diatoms; Aphanocapsa and Chroococcus (5 each) from cyanobacteria were the most saturated with species.

The greatest species richness of microalgae was recorded in May, the least - in October (Table 3). The floral complex of planktonic algoflora in all seasons of observations was made up of representatives of three phylums: Chlorophyta, Bacillariophyta and Cyanobacteria.

According to the quantitative analysis in May, the number of phytoplankton varied from 645.3 thousand cells/l at st. 7 to $3.8 \mathrm{mln}$. cells/l at st. 56 . The average number of planktonic algae was $2.1 \mathrm{mln}$. cells/l (in Lake Pskov - $2.6 \mathrm{mln}$. cells/l, in Lake Peipsi - $1.8 \mathrm{mln}$. cells/l) (Table 4). The biomass of phytoplankton varied from 424.3 $\mathrm{mg} / \mathrm{m}^{3}$ at st. 7 to $1.3 \mathrm{~g} / \mathrm{m}^{3}$ at st. 22 (average biomass $\left.0.9 \mathrm{~g} / \mathrm{m}^{3}\right)$. 
TABLE 4 PHYTOPLANKTON INDICATORS OF THE PEIPSI-PSKOV LAKE IN 2020

\begin{tabular}{|c|c|c|c|c|}
\hline Lake & $\begin{array}{l}\mathrm{N}, \\
\text { mln. } \\
\text { cells/l }\end{array}$ & $\underset{\mathbf{g} / \mathbf{m}^{3}}{\mathbf{B}}$ & $\begin{array}{c}\text { Cyanobacteria } \\
\text { in the total } N \text {, } \\
\%\end{array}$ & $\begin{array}{c}\text { Bacillariophyta } \\
\text { in the total B, } \\
\%\end{array}$ \\
\hline \multicolumn{5}{|c|}{ May } \\
\hline Pskov & 2.6 & 1.0 & \multirow{2}{*}{63.2} & \multirow{2}{*}{82.2} \\
\hline Peipsi & 1.8 & 0.8 & & \\
\hline \multicolumn{5}{|c|}{ August } \\
\hline Pskov & 24.4 & 5.9 & \multirow{2}{*}{90.0} & \multirow{2}{*}{84.1} \\
\hline Peipsi & 11.5 & 2.2 & & \\
\hline \multicolumn{5}{|c|}{ October } \\
\hline Pskov & 12.0 & 3.2 & \multirow{2}{*}{78.5} & \multirow{2}{*}{82.6} \\
\hline Peipsi & 5.1 & 1.9 & & \\
\hline
\end{tabular}

*N - abundance, $\mathrm{B}$ - biomass

In August, the number of phytoplankton ranged from $2.9 \mathrm{mln}$. cells/l at st. 5 to $49.4 \mathrm{mln}$. cells/l at st. 27 . The average number of microalgae at all stations of the study was $16.2 \mathrm{mln}$. cells/l (in Lake Pskov - $24.4 \mathrm{mln}$. cells/l, in Lake Peipsi - $11.5 \mathrm{mln}$. cells/l) (Table 4). The biomass of phytoplankton varied from $564.8 \mathrm{mg} / \mathrm{m}^{3}$ at st. 7 to 10.9 $\mathrm{g} / \mathrm{m}^{3}$ at st. 22. The amount of algae was $3.6 \mathrm{~g} / \mathrm{m}^{3}$, which is 4 times higher than in May.

In October 2020, the number of phytoplankton varied from $2.6 \mathrm{mln}$. cells/l at st. 43 to $22.2 \mathrm{mln}$. cells/l at st. 52 . The average number of planktonic algae was $9.7 \mathrm{mln}$. cells/l (in Lake Pskov - 12.0 mln. cells/l, in Lake Peipsi $5.1 \mathrm{mln}$. cells/l). Phytoplankton biomass varied from 1.1 $\mathrm{g} / \mathrm{m}^{3}$ at st. 43 to $5.8 \mathrm{~g} / \mathrm{m}^{3}$ at st. 52 (average biomass - 2.8 $\mathrm{g} / \mathrm{m}^{3}$; in Lake Pskov - $3.2 \mathrm{~g} / \mathrm{m}^{3}$, in Lake Peipsi - $1.9 \mathrm{~g} / \mathrm{m}^{3}$ ) (Table 4).

During the studied growing season, cyanobacteria prevailed in the number of cells at all stations of Lake Peipsi: from $44.1 \%$ to $95.4 \%$, and their share in the total population in August reached about 90\% (Table 4). In all seasons, representatives of the genera Aphanocapsa and Gomphosphaeria were dominant. Cyanobacteria of the genera Coelosphaerium, Merismopedia, Snowella in the spring, Aphanothece and Microcystis in the summer were also among the dominant species. Representatives of the department of Chlorophyta in the total number averaged 4.4-17.1\% with the highest rates in May. The proportion of diatoms was $5.1-14.8 \%$, with the maximum content also in spring.

The main contribution to the biomass of the planktonic algoflora of Lake Peipsi was made by representatives of Bacillariophyta (58.1-93.9\%). The most significant role in all seasons belonged to the genera Aulacoseira and Cyclotella, a significant contribution to the total biomass was made by large-cell forms of the genera Cymatopleura, Gyrosigma, Navicula, and Surirella. Representatives of the department of Chlorophyta in the total biomass accounted for $10.1-12.5 \%$, Cyanobacteria - 2.0-4.3\%.

The average seasonal indicator of phytoplankton biomass in the water area of Lake Peipsi-Pskov for the entire period of the study was $2.5 \mathrm{~g} / \mathrm{m}^{3}$, which is significantly lower than the long-term average and allows us to classify the lake waters as "moderately polluted". The average biomass in the water area of Lake Pskov was 3.4 $\mathrm{g} / \mathrm{m}^{3}$, and in Peipsi $-1.6 \mathrm{~g} / \mathrm{m}^{3}$.

According to the ecological characteristics in relation to the habitat in Lake Peipsi in 2020, the group of planktonic algae accounted for $54.5 \%$ of the total number of microalgae. The group of planktonic-benthic and benthic organisms, represented mainly by diatoms, accounted for $27.9 \%$ and $13.9 \%$, respectively. The inhabitants of growth were $3.3 \%$, intertidal species of $0.4 \%$.

In relation to halobicity in the planktonic algoflora of the lake, more than half of the organisms were indifferent (54.1\% of the total number). Halophiles was 9.4\%, galophobs $-4.5 \%$, oligogalobs was $2.0 \%$. One-third of the discovered data of microalgae in relation to salinity were not available.

In relation to $\mathrm{pH}$, most of the algae had no information (60.7\%). The group of alkaliphiles accounted for $23.0 \%$, indifferent - $11.9 \%$, acidophiles - $3.3 \%$, alkalibionts $1.2 \%$.

Standing-flowing waters were preferred by $25.8 \%$ of microalgae, standing - 7.0\%, flowing - 1.2\%. Information on rheophilicity was not available in $66.0 \%$ of the detected species.

Geographical analysis of the phytoplankton of the Peipsi-Pskov Lake showed that the majority of algae were cosmopolitan (61.1\% of the total number). Boreal species accounted for $8.6 \%$, Arctic and holarctic forms accounted for $4.9 \%$, and Arctoalpine forms - 2.0\%. A single circumboreal species, Euglena korshikovii Gojdics, was found in Lake Peipsi. The distribution data did not include $25.0 \%$ of microalgae.

To determine the level of organic pollution and the degree of anthropogenic load on the biogeocenoses of the Peipsi-Pskov Lake, a saprobiological analysis was performed (Table 5).

TABLE 5 VALUES OF THE SAPROBITY INDEX AT DIFFERENT STATIONS OF THE PEIPSI-PSKOV LAKE IN 2020

\begin{tabular}{|c|c|c|c|}
\hline \multirow{2}{*}{ Stations } & \multicolumn{3}{|c|}{ Month } \\
\cline { 2 - 4 } & \multicolumn{4}{|c|}{ Lake Pskov } \\
\hline \multicolumn{4}{|c|}{ October } \\
\hline 22 & 1.83 & 1.81 & 2.00 \\
\hline 52 & 1.82 & 1.90 & 2.03 \\
\hline 51 & 1.78 & 1.74 & 2.12 \\
\hline 27 & 1.88 & 1.69 & 2.02 \\
\hline Average & $1.83 \pm 0.04$ & $1.79 \pm 0.09$ & $2.04 \pm 0.05$ \\
\hline \multicolumn{5}{|c|}{ Lake Peipsi } \\
\hline 56 & 1.72 & 1.66 & - \\
\hline 43 & 1.87 & 1.69 & 1.93 \\
\hline 57 & 1.78 & 1.63 & 1.84 \\
\hline 91 & 1.71 & 1.80 & - \\
\hline 10 & 1.95 & 1.84 & - \\
\hline 5 & 2.03 & 1.72 & - \\
\hline 7 & 1.96 & 1.58 & $1.89 \pm 0.06$ \\
\hline Average & $1.86 \pm 0.13$ & $1.70 \pm 0.09$ & \\
\hline
\end{tabular}

Most of the microalgae was a beta-mesosaprobic. The values of the Pantle-Bukk saprobity indices ranged from 1.58 in August at st. 7 (Lake Peipsi) to 2.12 in October at st. 51 (Lake Pskov). The average saprobity index for the entire study period was 1.82 , which corresponds to the 
beta-mesosaprobic zone of self-purification, the III quality class - "satisfactory purity".

\section{CONCLUSIONS}

According to the results of hydrochemical analysis, the values of the recorded indicators in the Peipsi-Pskov Lake in 2020 are comparable with the data of long-term studies and generally did not exceed the MAC. The concentrations of biogenic substances were higher in Lake Pskov, which indicates more active eutrophication processes in the southern part of the Peipsi-Pskov reservoir.

In the phytoplankton of the Peipsi-Pskov Lake during the growing season of 2020, 244 species taxa of phytoplankton with a rank below the genus from 8 phylums were identified. The floral complex of the planktonic algoflora consisted of the phylums Chlorophyta, Bacillariophyta, and Cyanobacteria. The greatest species richness of microalgae in the lake is observed in the spring season (184 species), the least-in the autumn (134 species).

The average number of phytoplankton in the PeipsiPskov Lake over the entire study period was $9.5 \mathrm{mln}$. cells $/ \mathrm{l}$ with absolute dominance of cyanobacteria. The average biomass was $2.5 \mathrm{~g} / \mathrm{m}^{3}$ with the largest contribution of diatoms.

Ecological and geographical analysis of phytoplankton has shown that freshwater widespread planktonic species predominate in the Peipsi-Pskov Lake, preferring slightly alkaline waters.

The data of saprobiological analysis indicate moderate pollution of the Peipsi-Pskov Lake, which makes it possible to attribute its waters to the III class of quality.

\section{ACKNOWLEDGMENTS}

This work was partially supported by the Russian Science Foundation (Grant № 20-64-46018)

\section{REFERENCES}

[1] Pskov-Peipsi Lake. T. Timm, A. Raukas, Yu. Khaberman, A. Yaani, Ed. Tartu: Eesti Loodusfoto, 2012.

[2] G. T. Frumin, N. A. Malysheva, "Water quality changes in Lake Pskovskoe (2000-2018)," Transactions of Karelian Research Centre of Russian Academy of Science, Limnology, no. 4, pp. 3239, 2020.

[3] V. A. Rumyantsev, V. G. Drabkova, A. V. Izmailova, Lakes of the European part of Russia. St. Petersburg: LEMA, 2015.

[4] T. V. Drozdenko, S. G. Mihalap, "Structural and taxonomic diversity and ecological features of phytoplankton in the Velikaya River (Pskov region)," Vestnik Tomskogo gosudarstvennogo universiteta. Biologiya, no. 41, pp. 118-134, 2018, https://doi.org/10.17223/19988591/41/7
[5] A. Basset, G. C. Carrada, M. Fedele, L. Sabetta, "The equilibrium concept in phytoplankton communities.," Encyclopedia of Ecology, Vol. 2, pp. 1394-1402, August 2008. [Abstract]. Available: ProQuest, http://www.umi.com/proquest/, [Accessed January 15, 2021], https://doi.org/10.1016/B978-0080454054.00711-4

[6] C. Liu, C. Liu, H. Shen, "Seasonal variations of phytoplankton community structure in relation to physico-chemical factors in Lake Baiyangdian, China," Procedia Environmental Sciences, vol. 2, pp. 1622-1631, December 2010. Available: ProQuest, http://www.umi.com/proquest/, [Accessed January 15, 2021], https://doi.org/10.1016/j.proenv.2010.10.173

[7] N. Zivana, M. Buzancic, G. Kuspilic, B. Grbec, S. Matijevic, S. Skejic, I. Marasovic, M. Morovic, "The response of phytoplankton community to anthropogenic pressure gradient in the coastal waters of the eastern Adriatic Sea," Ecological Indicators. vol. 56, pp. 106115, September 2015. Available: ResearchGate, https://www.researchgate.net/ [Accessed January 15, 2021], https://doi.org/10.1016/j.ecolind.2015.03.018

[8] I. S. Trifonova, Ecology and succession of lake phytoplankton. Leningrad: Nauka, 1990.

[9] A. P. Sadchikov, Methods of studying freshwater phytoplankton: methodological guidelines. Moskow: Universitet i shkola, 2003.

[10] GOST 31861-2012. Water. General requirements for sampling. Moscow, 2014.

[11] Environmental normative document (Federal)14.1:2:4.3-95 Methods of measurement of mass concentration of nitrite ions in drinking water, surface water and sewage of photometric method with Griess reagent. Moscow, 1995 (edition 2011).

[12] Environmental normative document (Federal)14.1:2:4.4-95 Methods of measurement of mass concentration of nitrate ions in drinking water, surface water and sewage of photometric method with salicylic acid. Moscow, 1995 (edition 2011).

[13] Environmental normative document (Federal) 14.1:2:4.50-96 Methods of measuring the total mass concentration of total iron in drinking water, surface water and sewage of photometric method with sulfosalicylic acid. Moscow, 1996 (edition 2011).

[14] Environmental normative document (Federal) 14.1:2:4.112-97 Methods of measurement of mass concentration of phosphate ions in drinking water, surface water and sewage by the photometric method with ammonium molybdate. Moscow, 1997 (edition 2011).

[15] Environmental normative document (Federal)14.1:2:3:4.123-97 Methods of measurement of the biochemical oxygen demand after the n-days of incubation (BOD full) in surface freshwater, groundwater, drinking water, sewage and effluent sewage. Moscow, 1997 (edition 2004).

[16] Environmental normative document (Federal) 14.1:2:4.276-2013 Methods of measurement of the mass concentration of ammonia and ammonium ions in drinking water, natural water and sewage by photometric method with Nessler reagent. Moscow, 2013.

[17] Methods of studying biogeocenosis of inland water bodies. F. D. Mordukhay-Boltovskiy, Ed. Moscow: Nauka, 1975.

[18] V. M. Shmidt, Statistical methods in comparative floristics. Leningrad: Leningradskiy universitet, 1980.

[19] F. Pantle and H. Buck, "The biological monitoring of the waters and the presentation of the results" in Gas and water compartment, Bd 96, № 18, 1955, pp. 604-618. 